\title{
EDITORIAL: NEW MUSIC AND OLD COLONIALS
}

\author{
Christopher Fox
}

Colonialism is perhaps an unlikely topic for a TEMPO editorial but I want to pursue some ideas from Joanna Ward's article in TEMPO 294, 'Decentring and Dismantling: a Critical and Radical Approach to Diversity in Tertiary Music Education'. Ward writes that 'as long as we operate within the epistemological bounds of patriarchal, colonial musical and cultural hegemonies, we will never achieve true change' (p. 75) and, although her article focuses on music in tertiary education, the 'patriarchal, colonial' mentality inhibits change in every aspect of musical life.

I have complained in previous TEMPO editorials about the lingering influence of patriarchy in new music and a glance across the contents listings of recent issues will quickly demonstrate that my complaints have not been entirely effective. TEMPO is still a journal in which a disproportionate amount of space is devoted to men writing about music by men. This is not to suggest that this writing should not be in these pages, only that it should sit alongside at least as much writing that represents the rest of humanity.

This ought to be easy to fix but perhaps there is more to the problem than a balancing of gender statistics? Perhaps we need to think about new ways of writing about music? Perhaps the favoured format of so much of this writing - writer A discusses the music of composer $\mathrm{B}-$ is itself problematic, perpetuating the concept of the Master Musician, with all its patriarchal baggage?

As Joanna Ward suggests in her article, if we want to change ideas about music, to dismantle the exclusive structures that have grown up around music creation, education and reception, then a key strategy is one of decentring. We need to rid ourselves of preconceptions that designate some musical practices as being more important than others, simply because they originate in a setting that has, historically at least, been deemed more 'central'.

In geo-political history the idea of 'centres' and, their corollary, 'peripheries' has been institutionalised in colonial empires. Colonialism is not exclusively a European problem, but over recent centuries it did become a European habit. It was Europeans who occupied the territories that they decided to call 'The Americas', 'Australia', 'New Zealand', and so on, even though there were other people living there who had other names for those lands. It was Europeans who drew the arbitrary lines across the continent of Africa, collecting peoples into administrative entities in the same way that they collected the artefacts of those peoples into museums in Amsterdam, Berlin, Brussels, London and Paris.

We know all this, of course, even if those of us who live in Europe and North America seem remarkably reluctant to get rid of all the statues, all the names of streets, cities and institutions, that are such obvious reminders of our colonial past. But the colonial tendency is also 
residual in our intellectual and creative habits. The Venezuelan composer, Adina Izarra, who is profiled in this issue, alludes to the most obvious manifestation of the tendency, the way in which musicians and their music from the 'peripheries' are othered by 'centre'-based promoters, critics and - let's be honest - many listeners too. As she says, living in Ecuador I can be a composer, full stop. I do not have to prove that I am Latin-American.'

A more insidious colonialism informs the way in which arguments about musical creation have often been framed. Composer $B$ is important because they are the first to use technique $\mathrm{X}$, making an aesthetic land-grab that they then document in programme notes and lectures. Writer $\mathrm{A}$ is the first to write about B's deployment of $\mathrm{X}$ and so becomes complicit in the process, performing a critical validation of B's colonisation of $\mathrm{X}$ in the same way that the Berlin Conference of 1884-85 validated the European powers' 'scramble for Africa'.

In a decentred musical world things might be different. Composer $B$ would acknowledge all the other musicians on whose practice their own work was contingent and writer A would consider that work in its context; or (more realistically, perhaps, given many composers' self-absorption) the writer would enable the composer to understand better how their work was indeed part of this wider context and, beyond the aesthetic domain, part of the world at large.

It is with regret that we mark the death of Jerome Kohl. Dr Kohl's legacy will probably be his Stockhausen scholarship (Ian Parsons' article on KLANG in this issue cites his work on LICHT and KLANG), and in particular his book on Zeitmasse, ${ }^{1}$ but he was one of those quietly diligent researchers on whom so many other scholars' work depends. He translated many articles and was managing editor of Perspectives of New Music for many years, as well as being involved in the foundation of the Early Music Guild, now Early Music Seattle. Jerry Kohl was a clarinettist - during the Vietnam War he served as an army bandsman and completed his $\mathrm{PhD}$ on Serial and Non-Serial Techniques in the Music of Karlheinz Stockhausen from 1962-1968 at the University of Washington in 1981.

Given the quality of his work it will surprise some readers to discover that Dr Kohl worked for many years as an administrative assistant in the University of Washington, first in the Classics department and more recently in the Political Science department. As the University's tribute to Dr Kohl put it, his choice of occupation was motivated by 'a need for health insurance', but he 'continued to write and give lectures around the world while he was answering phones and sorting mail in our office'. His death, from a heart attack, was unexpected, and as another great Stockhausen scholar, Robin Maconie, told me, 'there was no inkling of any illness or deterioration. We were in the middle of a long conversation on the topic of [Stockhausen's] Konkrete Etüde and the mysterious "millimetre tape" that perplexed Schaeffer. I had been hoping for some time to persuade Kate Brett at CUP to publish the Richard Toop translation of Stockhausen's Texte 1 \& 2, which Jerry had been involved in readying'. He will be much missed.

\footnotetext{
${ }^{1}$ Jerome Kohl, Karlheinz Stockhausen: Zeitmasse (London: Routledge, 2017).
} 